\title{
Decentering Expected Voices and Visibilities through Connective Learning in a Feminist Transnational Bridging Pilot
}

\author{
Sarah York-Bertram, Marie Lovrod, Lisa Krol
}

\begin{abstract}
This paper outlines the learning opportunities that emerged when international students acquiring English for Academic Purposes joined Canadian undergraduates fluent in English for an Introduction to Women's and Gender Studies. Critical reflections provided by students, course facilitators, and the graduate student researcher were gathered through surveys, interviews, and focus groups that examined experiences of academic internationalization in feminist and language acquisition classrooms, co-designed to engage difference as a valuable resource in community and knowledge-building. Results included development of mutual mentoring relationships across a wide range of educational and cultural backgrounds; honing of international students' English-language skills through structured, intentional learning opportunities with others fluent in English; deepening awareness of non-western and Indigenous contexts as sites of critical knowledge production; and evidence that international and local newcomers to university campuses have much to offer one another. For everyone involved, there were opportunities to reflect critically on both subject matter and pedagogies of community building; use accessible language to build connections; interrogate knowledge claims emerging from the many contexts that instructors and students brought with them into learning conversations; and practice collaborative knowledge-building by probing the effects of local and global power systems in the learning pathways of students, instructors and institutions.
\end{abstract}

KEYWORDS internationalization, bridging courses, feminist qualitative research, mutual mentoring, connective learning

Feminist scholars, concerned with the ways social positions are conditioned by experiences of dominating power systems, argue that academic internationalization may leave the state and the institutions that integrate its power un-interrogated, by celebrating multiculturalism without critical attention to structural inequities (Weigman, 2012). Diversity rhetorics remain amenable to capitalist manipulation, including in systems of higher education, as shaped by colonialist legacies and neoliberal agendas (Ahmed, 2012). Access, inclusion, and available resources influence student retention and outcomes (Murphy \& Zirkel, 2015, p.33). Racialized students are less likely to experience a strong sense of belonging in North American academic settings than white students (Murphy \& Zirkel, 2015, p.28, 31), and for Indigenous communities 
in Canada, "secondary school completion and postsecondary educational attainment are decreasing, while incarceration rates among youth are significantly increasing" (Wanyena and Lester-Smith 2015, p. 93), largely due to chronic underfunding of Indigenous education and communities. Aritha Phiri (2015) traces the "impact of austerity" (13) discourses on the retrenchment of institutional processes of "othering" to suggest that "feminists in academia should be actively involved in creating alternative, unconventional structures of empowerment" (23) that illuminate better pathways forward.

Amidst such challenges and tensions, accepting accountability for involvement in structures that participate in systemic violence can open doors to community-building across disparities. Because Women's and Gender Studies works to develop promising practices of inclusion within and beyond the academy, often in critical tension with received knowledge politics, many students find the introductory class foundational to assuming an empowered role in their studies and lives. Inclusive content and interactive pedagogies offer a productive site for bringing communities of students together to learn in a context where differences can function as critical resources in unpacking the implications of transnational flows of knowledge, students, jobs, resources and power. The study described in this paper paired the Introduction to Women's and Gender Studies (WGST) with an advanced class of international students acquiring English for Academic Purposes (EAP) to interrogate Anglo-conformity and other factors that shape inequitable participation in undergraduate classrooms, and to examine potential challenges and benefits involved in collaborative learning across variable fluencies in the language of instruction.

Gender is a salient factor in the academic trajectories of multiple student constituencies. At our university, there are more male than female international students, owing to downward pressures on the education of women and girls under neoliberal globalization. Partners of international faculty and graduate students may also become isolated in contexts not well equipped to support community integration. While our students' union raises scholarship funds that encourage women from abroad to apply, comprehensive institutional shifts are needed at the levels of faculty and student recruitment, curricula, and community engagement to facilitate more equitable learning opportunities. Conversely, more Indigenous women than men enter our university, in part, because Indigenous men have joined other male workers from across Canada in regional resource extraction industries. Meanwhile, like many of their Indigenous and international peers, new students from rural communities, more of them women, are likely to be first generation post-secondary scholars. Navigating so many complex social positions and value systems may lead to multi-directional misunderstandings, particularly in contexts where implicit structural biases remain unquestioned.

Because women and other minoritized groups struggle to participate fully in reshaping knowledge politics in more democratic directions, Wiegman urges feminist scholars to "engage the larger and better-funded internationalizing projects of our universities [...] inhabiting the field and the university" (cited in Joseph, 2013, p. 136) through critical inclusion strategies. Brydon (2011) demands "a new form of globally involved interdisciplinarity advocating for the university as a forum where . . previously excluded modes of knowing may enter the 
discussions" (p. 98). She envisions academe as a site of "cognitive justice," promoting "goals of reciprocal knowledge production based on dialogues across differences and attempts to compensate for power differentials" (101). For Odora Hoppers (2008), "The education of the future needs to invest in the building of bridges, [that ...] enable us to embrace the 'stranger,' and people who are not personally known to us" (3). She critiques the "absence of bicultural experts" needed to build "on combined strategies anchored in multiple knowledge systems" (3). By supporting intentional learning coalitions across student communities usually kept separate until they converge in large front-facing lecture halls steeped in western knowledge frameworks, we sought to "deconstruct commodified social relationships" and open the transgressive "possibility of being, thinking and living 'otherwise" (Motta, 2013), together.

\section{Context}

According to Statistics Canada, immigration is currently Canada's main source of population growth (2012). Over 6.6 million people in Canada speak a language other than English or French at home. This demographic change is causing massive shifts in Canadian society that will require new approaches to education, employment, and immigrant integration (Guo \& Hébert, 2014). However, post-secondary administrators have demanded that EAP students first prove English proficiency, significantly delaying access to immersive learning opportunities. In this way, international language learners may become subject to systematic discrimination in classroom and funding allocations (Guo \& Hébert, 2014, p.174), despite paying steep tuition differentials. At our university, EAP classes are separated from the main campus by a major roadway, a large parking garage, and vast sports fields.

This spatial distribution of people and resources discourages more pluralist forms of education (Cummins, 1991; Hébert, 1990). Though well-funded French immersion programs are fairly common in Canada, immersion programs for EAP students are often missing, even though experts recommend cognitive, academic, and strategic language teaching and learning that build multilingual and intercultural skills (Guo \& Hébert, 2014, pp.181-182). At our institution, the introductory WGST course has proven well-suited for immersive intercultural teaching and learning agendas when, as Fraser (2009) recommends, issues of misdistribution in the economic sphere, misrecognition in the socio-cultural sphere, and misrepresentation in the political sphere are addressed, including as manifested in post-secondary institutions.

Recent scholarship identifies feminist interactive teaching strategies as vital to meaningful connective learning in multiple arenas of academic preparation and professionalization (e.g. Crawley, Lewis \& Mayberry, 2008; Motta, 2013; Kannon, 2014; Liao \& Wang, 2015). Our project, however, addresses a specific kind of "bridging" class. Often designed to move students toward formal academic admission, these classes are increasingly necessary as universities and colleges compete for regional and international students-whether returning adult learners, traditional-age students from underfunded reserve schools, those who may not meet direct entry requirements, or those for whom the official language of instruction is not their first. Bridging courses provide critical skills as well as confidence-building experiences, smoothing student pathways toward compliance with academic standards for pursuit of formal degree 
studies. Our experience demonstrates that treating student experiences and knowledge as relevant to their ambitions and to the critical work of challenging and reframing knowledgepower systems enhances intercultural academic learning.

Anglo-centrism, gender biases and cultural domination are thriving vestiges of colonialist legacies, particularly in the context of internationalizing agendas that emphasize monolingual participation on Canadian campuses. Attending to Indigenous histories, languages, communities and aspirations, as well as the multiple displacements produced by globalizing imperialisms, is vital to informed participation in Canadian education systems. Our bridging class engages critically with, but is not removed from these realities. Rather, feminist classrooms can provide spaces to "historicize, contextualize, and politicize differences as a sustained critique of 'homogenizing' ... approaches to diversity, which erase inequality by detaching difference from a critical analysis of power" (Karpinski, 2007, p. 46). Hobbs and Rice (2011) argue that queer theory, trans studies, Indigenous and transnational feminisms have inspired many to "rethink the assumed subject of feminism" (pp. 134-144), troubling notions that women are a primary focus or presuming any "common history" grounded in western assumptions (Hemmings, 2001, p. 193). Canada's Truth and Reconciliation Commission, for example, unsettles notions of shared nationalist histories, acknowledging gender as a prominent factor in harm done to First Nations relational networks, while affirming the relevance of Indigenous knowledges to more inclusive and sustainable futures.

Because histories of inequities are complex and uneven, it is important to note that categories of "international" and "domestic" students proved to be a false binary from the beginning. International students entered our classroom from Canadian public schools as well as educational systems from abroad; nor were they the only ones who needed support in listening, speaking and writing English. Increasingly, through successive iterations of this class, those who would be considered fluent English speakers have been taking advantage of the grammar and writing skills training offered by the language instructor. Meanwhile, the WGST facilitator is involved in ongoing reconciliation research, is learning Chinese, and has since taught transnational feminisms for English language learners in China.

\section{Back-Story}

Building institutional capacity to offer bridging programming began several years ago with efforts to enhance cross-cultural learning opportunities in our WGST program. In partnership with the Language Centre, we generated a critical mass of evidence supporting the value of feminist learning engagements with internationalization agendas. At our university, international students learning English for academic purposes attend classes that operate on separate semester schedules, with distinct start and end dates, and different classroom hours than the main campus. While international students are eager to find Canadians with whom to share learning conversations, mutual lack of familiarity with respective national histories can be limiting. In learning conversations organized through our international student centre, participants have been encouraged to avoid controversial topics including politics, religion and sex, in order to keep the focus on basic language acquisition. Transnational feminists, however, 
have demonstrated that productive tensions can emerge in the context of mutually respectful engagements with controversy (Snyder, 2005). An urgent need to communicate clearly across structural barriers can support language acquisition, while undoing normative assumptions and patterns on all sides.

With the Language Centre's Cultural Activities Coordinator, we began to find ways around the conflicting timetables that had been a persistent barrier to collaboration across student communities. Initially, we organized five in-class meetings between advanced English language learners and senior feminist methodologies students. Our objective was to support conversational learning partnerships that prepared students from both groups to consider what it means to engage in qualitative research that seeks to redress power imbalances in knowledge development. Students from both groups learned more about one another's national histories and related structural inequities, including Canada's persistent colonialist practices. The goal in these initial sessions was to demonstrate the value of facilitated shared learning opportunities provided through a bridging program involving EAP students and undergraduate peers whose first language is English. Ultimately, we wanted members from both groups to share access to introductory WGST classrooms for an entire semester, in which they would be encouraged to value mutual contributions to conversations about power and knowledge.

After we provided careful analysis of evaluative commentary from all participating students in several consecutive courses involving international EAP and senior feminist methods students, the university agreed to remove administrative barriers and support a pilot Introduction to WGST based on intentional learning partnerships among international and "homegrown students" (Waynenya \& Lester Smith, 2015). An honours graduate from our program who had taken part in one of the early linked EAP and feminist methods classes, became graduate research assistant on the project. Her previous learning partnership with an international student helped shape her research approaches. She understood the relational complexities and learning possibilities that could emerge in such an intentionally connective learning space and was aware that barriers between EAP students and fluent speakers of English are not sufficiently interrogated in post-secondary internationalization projects.

\section{Mobilizing Qualitative Research in the Feminist Bridging Classroom}

Design. Qualitative studies, often drawing on in-depth interviews, surveys and collaborative evaluations, have examined the adaptability of feminist pedagogies to a wide range of transitional learning contexts including English-language acquisition (Liao \& Wang, 2015); community-engaged research (Ganote \& Longo, 2015); ally skills-development in sensitivity training for therapists (LaMantia, Wagner \& Bohecker, 2015); conceptualization of nonpatriarchal and pro-equity masculinities in couples and family therapy (Mui-Teng Quek, Eppler \& Morgan, 2014); nursing student empowerment in community practice (Falk-Rafael et al., 2004); and the co-construction of learning "heterotopias," where inclusive pedagogies help shift the ways diverse participants "encounter the world" (Kannon, 2014, p. 64). We sought to contribute to this literature, by bridging classrooms and student constituencies to facilitate opportunities for intercultural learning. For our study, a designated Introduction to WGST 
course functioned as a primary research site where students, instructors, and researchers learned together over one term. The class contained the same materials and learning objectives as any standard introductory WGST course at our institution. What distinguished this course from others, however, is that it was paired with an advanced EAP class, offered through the university's Language Centre. Parallel structures and assignments across both classes enabled EAP students to workshop WGST coursework as part of their language acquisition program, while providing the necessary support for completing an undergraduate course for credit. Homegrown and international students worked throughout the course in small groups designed to support relationship building. Students were encouraged to learn with and from one another through assignments, presentations, and group work.

Both the WGST and EAP courses functioned as learning laboratories for one another, since the EAP students mobilized the WGST content in their language skills training, and the WGST course drew on the experiences of all class members as a way to build critical thinking, writing, and project development skills. The mix of local and international students also created a unique configuration of world perspectives that enriched class discussions. A graduate student researcher (GSR) conducted a qualitative assessment of students' experiences for the purposes of improving future class design for possible emulation by other academic units, and coordinated interviews with course facilitators. Ethics approval was obtained for this research.

Participants. Formal participants in this study were six international students, four of whom were EAP students; eleven homegrown undergraduates; and one post-doctoral candidate auditing the course, each represented below using pseudonyms. All 30 students in the strategically smaller classroom were informed about the pilot study on the first day of class, and became de facto members of the larger collective participant group, with the option to withdraw from the course if they did not wish to be part of the study. Everyone stayed. Both course facilitators contributed responses and participated in the study, one as principal investigator and instructor for the WGST course, the other as the advanced EAP course teacher. The GSR also contributed study responses.

Measures. The GSR worked with facilitators from both courses, as well as interested participating students, to design and execute a series of evaluative instruments, investigating learning experiences at all levels of involvement in the course. The GSR sat in on both sets of classes, making observations. Students' experiences and comments were tracked through interviews, questionnaires, photo-voice projects, and summary focus groups. During interviews, the GSR found that students wanted to process and speak back to what they were learning. She was in a position to mentor students experiencing major worldview shifts, having been through a similar process herself. Students needed emotional support as they reflected critically on the effects of global politics in their daily interactions. Thus, the GSR became a confidential resource for students who could share any concerns openly with her, without worrying about academic or social consequences. 
The first round of interviews took place in the second month of class, after co-created qualitative instruments received ethics approval. The GSR met individually with students who were invited to respond to questions exploring how they were experiencing the class, and any supports that would serve their efforts to share perspectives in study groups and larger class discussions. Students were also given an opportunity to generate photo-voice projects in which they captured photographic images to illustrate their experiences in the course, augmenting them with captions and written commentary. In the third month of the course, the GSR engaged with each participating in-class study group, and organized a separate focus group to discuss how participants experienced working in intentional groupings across the course and what they had learned through the process, including reflections on any challenges they faced together.

A final interview round was conducted at the end of the course with individual students and course facilitators. The GSR asked questions assessing cross-cultural learning outcomes and overall impressions of the learning environment. Students also had ample opportunities to give feedback to the GSR during the entire term, as they wished. Finally, the language skills of participating EAP students were assessed by comparing English proficiency from earlier to later written assignments, and charting improvements in comparison with EAP students who were not registered in the course.

\section{Cooperative Learning and Connective Knowledge Building}

According to Elizabeth Ellsworth (1997), open-ended co-operative learning depends on recognizing that classroom contexts always engage partial, incomplete and circumscribed knowledge models. Educators, then, have unique opportunities to create welcoming spaces for knowledges with which they may not be familiar, just as students are not entirely familiar with the specific subject matter addressed. Sharon Rosenberg (2010) sees this insight as key to feminist pedagogy and the "faltering knowledges" that emerge in engaged learning, which can be both liberatory and painful (Kannon, 2014, p. 53). Certainly, students and instructors carry into the classrooms they share, the lived effects of social biases. The discomfiting partiality and frailty of all human knowledge requires willingness to work as curious allies, drawing on diverse standpoints to unpack the complex implications of local, national and global knowledge-power systems.

Class planning for our project involved multiple strategies to facilitate critical cooperative learning across diverse state, educational, and cultural systems. Although critical reflection is important to every WGST class, conscious engagements with structural barriers to immersive interactions among international and local students within our own institution set this course apart. Intentional self-selected groups of three to seven members supported all participating students in gaining familiarity with one another around shared interests in a specific course topic. Students were invited, on the midterm, to raise questions for their peers, in preparation for a self-evaluative exercise that led to lively exchanges about what they were learning, how they were using that knowledge in their daily lives, and what baffled or frustrated them.

The class was front-loaded with various "getting to know you" interludes that reflected 
on class and institutional processes as resources for critical inquiry. Students were asked to consider any and all aspects of their coursework, through "meta-texts" on completed assignments, and other elements of the course. These short, free-wheeling, self-reflexive evaluative pieces addressed student experiences of each course assignment, what they liked or did not like about completing the required task(s), what they did or did not learn, what they thought they had achieved in the assignment and so on, in the space of about a page. Students were also invited to earn bonus marks by writing responsive meta-texts about campus and community-based events germane to the class. One student commented: "I really like to write the meta-texts. I've never seen a professor asking us, 'How did you find the class? What were the challenges? What would you like the class to do?' you know? I wish we could do that in every class."

Course facilitators and the GSR all played a role in fostering connections among participants. The Language Instructor reviewed WGST course textbooks, noting themes, unpacking inherent cultural assumptions, unfamiliar visuals and terminologies. She fitted grammar lessons that once stood alone in language classes into the context of WGST course content for international students. Considerable time was spent in the WGST class compensating for missed cues and revising approaches at the last minute to accommodate new insights about westernisms in the course design, making improvements that would better accommodate class goals. Everyone was positioned as both a learner and a mentor. Students mentored facilitators in developing better learning strategies. Facilitators mentored students in learning to work through communication challenges. The graduate student mentored students and facilitators, providing vital information about group dynamics and, in turn, was mentored as a researcher.

The class provided a space where "faltering knowledge" was recognized as useful. Students made the effort to interrogate the implications of "internationalization" for all of the nations represented in the room, including diasporic, settler-colonial, First Nations and Métis members, and what it might mean to develop mindful, critical perspectives on institutional internationalization processes, even while engaging them as a form of career development. As the class evolved, expected voices and visibilities began to shift toward new sets of questions for students and project facilitators. 


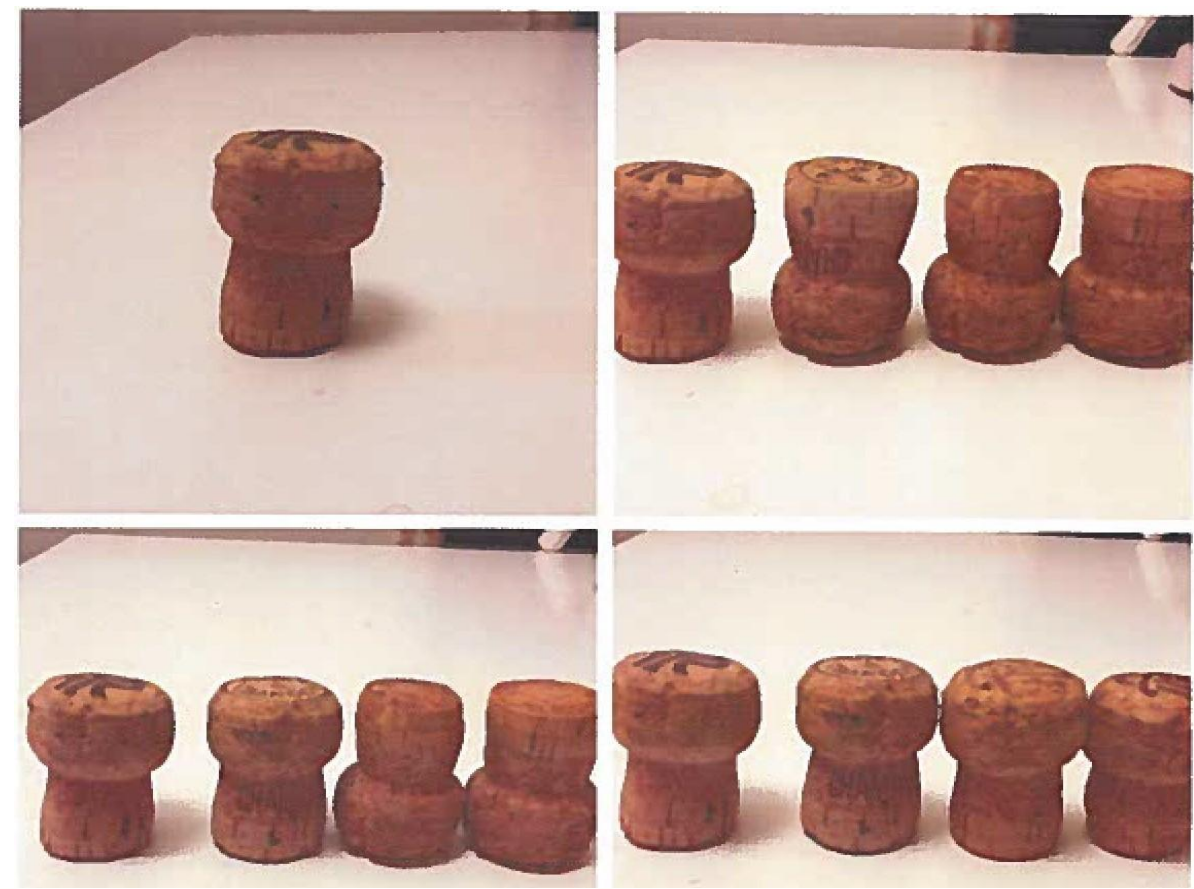

Realize and Share: Moving from Isolation to Integration. "I had a really good experience with my first in-class group. At the beginning of the class, I was too shy to talk with them; however, we then become friends. They are helpful, patient and friendly; they could always get my point even if I did not speak very good English. We not only discussed academic things but also shared stories in our lives."

\section{Decentering Dominant Expectations}

As Russo (2006) argues, the West is often assumed to embody a space of equality, freedom, and democracy, while, as Grewal (2005) suggests, the Two Thirds World is considered a space that needs to be "rescued" (p.179). Davis (2010) holds that comparative frameworks help break down these binaries, by encouraging students to think critically about "difference as a relational effect" that is "both discursively and materially produced" (pp. 142-143). While course content, feminist pedagogical strategies, and multiple open channels of communication assisted the goals of this pilot study, much of the learning came from something the facilitators could not have orchestrated: what students brought to the class from their own relationallyembedded experiences and contexts, and their willingness to struggle and learn individually and together across unfamiliar standpoints.

Immersive, cross-cultural, and pluralist methods can disrupt dominant western knowledge frames and feminisms, which may not be as familiar in multi-lingual/inter-cultural contexts. The GSR and course instructors learned more about this by listening to student feedback. As Joel, an EAP student, commented in an early interview, "Sometimes we talk about histories and cultural things that [international students] don't know. Since we don't know, we have nothing to talk about." Jill, a Canadian student, commented, "I guess you tend to think of 
feminism as a western thing. I was talking to my sister yesterday and she said, 'Oh, you must focus on North America because that's where feminism happens." Xander, another EAP student, noted that "The class is very western and focused on Canadian culture [...] Chinese people really do want equality of men and women." As students shared their impressions, we incorporated more activities that encouraged cross-cultural understanding. As a result, the mistaken notion that feminisms are located primarily within the West was troubled.

Personal experience and place-based knowledge had an important function for students, giving them authority when sharing their perspectives to bridge knowledge gaps. Alicia, a Chinese EAP student, commented, "I share my ideas, like, this is what's happening in China." One focus-group participant noted, "The international student in our group talked about what it was like in Nigeria. When it came to participation, she definitely brought different ideas for us to think about." When asked how she shared her point of view, Hayley, a Canadian student, said, "I start with personal experience. I think that if you have any idea that someone might disagree with your point of view, you have a little bit of validation saying, 'this is why." Jill confirmed that she and her group mates also relied on personal experiences as she reflected on the ways she benefitted from hearing them:

One of my group members has a toddler so she knows about being pregnant and talks about how she was treated when she was pregnant. When we have discussions like that-I have no idea, I was the baby of my family. I've never seen my mom or anyone close to me pregnant. So I learn something when my classmates share their lived experience.

Perhaps one of the most powerful examples of cross-cultural and place-based sharing emerges in the story of our class's interaction with our institution's beloved Amati instruments. In the year we launched our bridging pilot, our College's Interdisciplinary Centre called for a transdisciplinary study of these rare seventeenth-century instruments for chamber quartet, designed to foster inter-unit capacities for and commitments to cooperative pedagogical and research activities. The Amati instruments were smuggled from France during WWI, then purchased by a local farmer and collector who eventually donated them to the university. A group in our class decided to adopt and bring a WGST lens to the project.

Students from participating disciplines presented their findings at a special banquet. Two of our bridging class students opened the evening's presentations. A fluent English speaker and classically trained musician reviewed the patronage system in Europe, reflecting on how disciplining and democratizing forces shaped musical customs and performances during Europe's expansionist period. However, women, Indigenous and enslaved peoples rarely played in noble chamber orchestras at the time, except as "oddities."

This introduction was followed by a spirited presentation by one of the EAP students on the Mongolian Morin Khurr, a stringed instrument originally threaded with horse hair, purported to have inspired the western violin, and traditionally played by men for male audiences. As women's rights became a more pervasive concern in nineteenth century China, 
women were permitted to take up special versions of the instrument, strung with hairs from the tails of female horses. Both students then presented an abbreviated trailer for Landfill Harmonic, a documentary that recounts how children raised in the garbage dumps of Cateura, Paraguay, have created an orchestra of stringed instruments made from refuse, to international acclaim. The clip concludes with the message: "People realize that we shouldn't throw away trash carelessly. Well, we shouldn't throw away people either." The presentation, which shifted focus from the remarkable Amati instruments themselves to questions of who may have been privileged to play or even hear them, was anchored by the international student who argued that musical instruments and the musicians trained to play them reveal deep truths about their embedded cultural contexts.

\section{Intentions to Connect, Learning from Disconnections}

Group work and in-class activities expanded students' perceptions of feminist efforts to promote social justice. In a focus group interview, Drew, a Canadian, told international and EAP students that

A big moment for me was when you guys did your presentations and it expanded feminism outside of the western context. It made it personal [...] It makes me think about the people in international feminist movements; do they just ignore North America's perspective of globalization?

For Drew, the focus is no longer on how North Americans perceive 'others,' but how international feminist movements respond to western-centrism. Further, as Brady, another Canadian student, commented, co-learning with EAP students caused him to consider language and Anglo-centrism in new ways, "Xander has taught me a lot about how hard it is to learn a language. Not only are they learning from us but we're learning from them."

During their one-on-one interviews, some homegrown students shared that working closely with international and EAP students made them extra conscious of their word choices and the power of language. Jill commented:

[Our teacher] talks about how important language is, how you have to be careful with the words you choose. Sometimes I'm worried I'll choose the wrong language. It might not sound feminist or be discriminatory without me knowing about it [...] I think that people have unconscious racism and sexism.

However, as Drew reflected, hesitancy in speaking up due to fear of saying something wrong could prevent learning:

It's hard just to say something to see how it sounds. And maybe you think it's wrong after you said it. Or maybe all the other people think it's wrong. But there's something really nice about being able to put out an idea and being like, "Um. OK. Well, I [messed] up." (Laughs) 
Student feedback regarding hesitancy in speaking up during class discussions prompted course facilitators to arrange a conversational learning activity in which students formed parallel "speed-dating" circles. Students from the inside circle became partners to students on the outside circle. Instructors posed questions by and for students (previously gathered through the midterm) as prompts for short bursts of animated discussion. Every few minutes, the outer circle moved left so students could engage new partners. When it was over, students were invited to respond to the exercise. Two of the most important takeaways were: (a) difficulty in understanding readings and course content was not limited to language learning students and (b) many students initially felt hesitant about speaking up; all thought they were alone in their feelings. This exercise was invaluable in building a more supportive environment for enhanced student confidence in sharing critical perspectives.

Interrupting the typical front-facing orientation of the classroom creates new opportunities for discussion and allowed students to move beyond their stable study groups. Students were conscious of their physical location within the classroom. "A circle makes it easier to talk," Alicia said. Students' awareness of and concern about the spaces they co-inhabited in class could be understood as mutual care. They co-laboured as they exchanged their ideas, making room for each other through active listening and sharing.

With the assistance of instructors, EAP and fluent speakers developed strategies to navigate language barriers in the classroom. As Mark, a Canadian student, noted, "Sometimes I'll discuss what I want to say with my group members. They usually understand what I am saying, but not always, and then I have to think of other words to use or another way of saying what I want to say." Leah, an EAP student, commented that "After the lecture, me [sic] and my [EAP] classmates talk about it and I feel more confident to share my ideas with them. It's very helpful and useful for me to have the [EAP instructor], who helps me with the readings and assignments."

Fluent speakers took responsibility for assisting EAP students both with vocabulary acquisition and feeling welcome among their peers. Hayley stated,

When the international students speak up in class, I hear them say 'Sorry for my bad accent.' That's learned. Just because you have an accent that will require better listening skills on the part of the person you're talking to, it's not something you have to apologize for.

Brady understood that a large part of Xander's work in the classroom was listening: "When we're in our group, he just sits back and listens to us. He told us that when we talk he has to change English to how he understands it." To help his colleague follow discussions, Brady said that he would "talk to [Xander] in a way that he can take it in faster instead of using confusing words." "He's listening and that's how he participates. He's listening and learning how to speak English from us."

Relationships fostered in the classroom were not always limited to class time; students took initiative to communicate in the various ways available to them. Brady's group used text 
messaging regularly: "It's easier for [Xander] to communicate that way. We usually meet on campus and talk about class and stuff to see if he has questions. He says more when we text, though." Xander's group organized a dinner gathering before their presentation. He commented that "I never thought dinner would be like that. Chinese families always use the same dishes with rice to eat at supper. But we passed the dish around the table and each person dished up for themselves. We ate pasta. It was cool to learn some culture." During a group interview, Xander shared how group work showed him that "It's not as hard as I think it is to make Canadian friends."

Though international students' knowledges were valued, they were sometimes placed in a position of representing their national and ethnic identities by their peers. Some felt a sense of anxiety over representing their home countries. Alicia, who gave a presentation on human trafficking in China said, "Sometimes I feel afraid of their bias. Like, yesterday I was afraid of somebody asking a really offensive question like, "Whoa! Many Chinese people buy girls?!' but it does not really happen very often; luckily, that didn't happen.” Lauren, a student who moved to Canada from Uganda, had a more challenging interaction with a local student:

At the presentation, I can't remember her name, but she said, 'Thank God I'm here because I don't have to worry about this and that.' And I'm like, 'Yes, so count yourself lucky because not many people have the same privileges. Not everybody is "lucky".'

Deconstructing the power dynamics behind such constructions of "luck" became an important task for the class.

Shortly after her presentation, Lauren arranged a meeting with the GSR to discuss an experience she had on local transit when she witnessed and intervened in a situation of discrimination. Lauren watched a woman who appeared to be lost as she ushered her children onto a city bus:

This lady came here as a refugee from the Congo. She was dropping her son off to a soccer game but didn't know where the stadium was. When she got on the bus, she was on the phone with another mom trying to figure out which bus to take. She was speaking a different language and the bus driver said, 'Get on! We have to go!' After the bus had left she realized she was on the wrong bus. So she approached the driver and said, 'Can you help me? I think I'm lost. He yelled at her, 'If you weren't on the phone we could have figured out that you were on the wrong bus.' She said, 'Please, I'm so sorry. I was on the phone trying to get directions.' I could tell she didn't have very good English. The bus driver was so mad, he said 'Get off the bus, or else I'm calling the police.' What shocked me most was another lady came from the back and said, 'Lady, stop arguing or get off now. We live in peace here.' We are told that in Canada they protect you, your rights, and your freedom. But every time we get into situations like that, and I think that was discrimination of the highest order; it happens everywhere. It shocked me to see it in person and on a public bus. How can I tell my kids, 'It's OK; you're safe here?' No one should treat you like that. No one should disrespect you like that. 
Lauren's story was an important response to her peer's reaction to her presentation on life in Uganda. Her account of the incident on the bus challenges the narrative of Canadians as benevolent helpers and "peace keepers."

\section{Future Directions}

EAP students reported that the bridging course gave them a chance to speak English with native speakers, improved their reading, writing, listening, speaking and critical thinking skills, and readied them for taking future courses in a Canadian university. During a one-on-one interview with the GSR, Alicia said:

I really want to say thank-you for the WGST class—it gave me a hint, like, I'm ready for university. I think I can figure it out and I can handle it. And also I think the class gave me more of a chance to speak.

The EAP instructor had never seen such immense progress in speaking skills over a single term. Because EAP students wanted to contribute and be heard, they worked diligently to make themselves understood.

Anglo-centrism became apparent for everyone as First Nations, Métis and settlerdescended Canadian students recognized together that most had lost languages of origin to colonial assimilation processes via xenophobic educational systems, including residential schools. Several expressed interest in future language and travel study. Brady told the WGST facilitator that he felt the course would make him a better social worker. He took time on the final exam to note:

"[Xander] taught me so much about what it means to be an international student and I hope I made him feel welcome and accepted. I think the idea of the bridging program was great and I hope to see more in the future."

\section{Research Assistant and Language Instructor Reflections}

\section{Graduate Student Researcher}

I was selected to document and help evaluate the bridging pilot, because I had already been introduced to the issues surrounding internationalization on our campus in my senior undergraduate feminist methods course, where I had partnered with one of the visiting international students for a series of several visits between our respective classes. Ahmed, my conversational learning partner, was in the EAP program because it was required for admission to doctoral candidacy in History. I also planned to begin graduate studies in History, so we gravitated around our mutual interest. Most joint class time was spent becoming acquainted with our learning partners and reviewing films and readings, then discussing our responses in small groups. We also had one assignment for which we planned an outing with our learning 
partner/s and undertook participant observations in a public venue, then presented our findings to the class.

Mine and Ahmed's working relationship quickly became a friendship and time spent together started to spill outside of class. During one of our informal chats, I asked him questions about his family and homeland and he jokingly asked, "Are you doing a project on me now?" Of course, Ahmed was not my project, nor I his. His question haunted me, though, and provoked a major shift in our relationship. As Ahmed and I laboured to communicate, I learned how ways of knowing are entwined with language and how much can be lost in translation. I began to think more critically about Anglo-centrism, the ways I benefitted from it, and the ways my friend was affected by it. Undertaking this research project helped me to extend what I had learned in that previous course. By using the bridging class as a social justice learning laboratory where students were frequently asked to reflect on their experiences within and beyond the classroom, we made space to engage how internationalization projects operate in our lives and to embark on deconstruction of dominating scripts.

\section{Language Instructor}

Since this pilot, additional WGST bridging classes have been completed with similar EAP results. In order to hasten empathies and understanding among class members, we have expanded the cross-cultural learning activities and concentrated them in the first weeks of the class. The bridging program has also been extended to include a large lecture class with similar objectives and a focus on quantitative analysis. Although international students have been quite successful in terms of grades in that class, they have not progressed with their language skills to the same extent due, in part, to discussions and group work not holding as central a role in course organization. Lectures are largely reviews of assigned readings and students are not asked to contribute their perspectives or experiences. In these larger courses, EAP students do not feel valued as knowers in the same way as they do in smaller bridging courses and, as such, are not as motivated to develop their language skills. Meanwhile, the WGST Intro has acquired a positive reputation among international students. We started with four international EAP students in the pilot; the second term we had nine; and the third class had twenty-one students applying for fifteen available seats, which is amazing given that WGST was largely unknown among international students in the pilot year.

The program has now grown to include a slightly less advanced level of EAP students taking a Study Skills class for credit. These same students then move on to a higher level of English language training and are paired with WGST or other social science classes, chosen because they, too, are likely to provide situations where international students' contributions can become valued elements in course delivery. Internal institutional data developed since our study bears out the long-term successes of intercultural bridging in language learning. 


\section{Conclusion: Building Intercultural Learning Bridges}

Maparyan (2012) remarks that:

[WGST] at this particular historical moment appears as a multivalent, poly-vocal site of convenience for multiple overlapping and at times contradictory conversations about social change, social justice, human empowerment, environmental restoration and, increasingly, spirituality [...]; people 'show up'... as students and as faculty members, because they desire to talk about these things writ large, not simply because they desire to 'study women' or 'are feminists,' and because they sense it is safe or even possible to do so there in ways that it is not in other sites. (p.19)

This apparent convenience invests the WGST classroom with potentially transformative resources for students who want to pursue cognitive and social justice. However, we would argue that communities of critical pedagogical practise can have transformational impacts in many classrooms, using intersectional feminist, Indigenous, critical race, queer, transnational and critical disabilities studies approaches. Though feminist theorists rightfully call into question the "progress narratives" employed in telling the histories of western feminisms, for the ways in which they may be complicit with imperialisms (Braithwaite et al., 2004, Hemmings, 2011; Wiegman, 2012), the hope for "progressive" shifts in relational capacities that enable new solidarities does hold important imaginative possibilities. As Drew commented in a group interview, "Maybe imagining that ideal future is part of the solution." "I think that these problems cannot be solved in the short term," Alicia added.

Overall, student participants endorsed our opening premise, that connective learning and confidence-building are supported when students must find inventive ways to share their ideas in pluralist classrooms. In the context of this bridging pilot, EAP students were seeking a way to articulate their complex ideas in an acquired language. Fluent English speakers wanted to frame complex ideas in accessible terms for peers from their own and other education systems. Course facilitators wanted to make the challenges posed by and to feminist analysis legible in WGST and language learning classrooms with multiple objectives, including content-rich language immersion and critical study of normative interpersonal, institutional and international power relations. Promoting structural change at our university created a space in which to decenter multiple voices, visibilities, subjects and assumptions in support of community building through cognitive and social justice. Students explored inclusive approaches to learning and why they matter within and beyond the classroom. Everyone learned how to build solidarities by containing disagreements in sustained relationships, taking time to find out why someone might hold a particular perspective, and committing together, however imperfectly, to challenging inequities within and beyond the classroom through mutual processes of actualization. 


\section{Acknowledgements}

To Faith Baron, former Language Centre Registrar; Shauna Tilbury and Gina DiPaulo, Language Centre Activities Coordinators; Gloria Forbes (former Level-4 EAP Instructor), Mohammad Mansour Abush'r, Yaping Zhou, and Gina DiPaulo, who co-developed panel presentations for Saskatchewan's Teaching English as a Second Language and international Society for Teaching and Learning in Higher Education conferences; to the students who contributed to this study and colleagues who have expanded bridging options at our institution; to Language Centre Director, David Parkinson, who provided moral and financial support; the Interdisciplinary Centre for Culture and Creativity for a Catalyst Grant that funded our Graduate Student Researcher's work on this article; former Vice-Dean of Humanities and Fine Arts, David J. Parkinson, who contributed innovation funding and advice; and to our insightful reviewers, our heartfelt thanks.

\section{About the Authors}

Sarah York-Bertram was graduate student researcher on this project and is currently a PhD candidate in York University's Gender, Feminist, and Women's Studies programme, where she researches gender and feminist history and affect theory. Sarah holds a Canada Graduate Scholarship, and her SSHRC-funded Master's thesis won the 2013-2014 University of Saskatchewan Thesis Award in Humanities and Fine Arts.

Lisa Krol is the bridging coordinator for the Language Centre at the University of Saskatchewan. The Language Centre provides intensive English instruction for international students prior to undergraduate or graduate studies. Her M.Ed is in Special Education from the University of Saskatchewan.

Marie Lovrod (corresponding author), is associate professor and coordinator of Women's and Gender Studies at the University of Saskatchewan. Her research addresses intersecting constructions of childhood, youth and aging, in the context of traumas/resiliencies produced as localized effects of global capitalization. She values inclusive communities of practice in research and learning. Email: marie.lovrod@usask.ca 


\section{References}

Ahmed, S. (2012). On being included: Racism and diversity in institutional life. Durham, NC: Duke University Press.

Braithwaite, A., Heald, S., Luhmann S., \& Rosenberg, S (2004). Troubling women's studies: Pasts, presents, and possibilities. Toronto: Sumach Press.

Brydon, D. (2011). Globalization and higher education: Working toward cognitive justice. In Raphael Foshay (ed.), Valences of interdisciplinarity: Theory, practice, pedagogy (pp. 97-119). Athabasca University Press.

Crawley, S.L., Lewis, J.E. \& Mayberry, M. (2008). Feminist pedagogies in action: Teaching beyond disciplines. Feminist Teacher, 19(1), 1-12.

Cummins, J. (1991). Conversational and academic language proficiency in bilingual contexts. AILA Review: Reading in Two Languages, 8, 75-89.

Davis, D. R (2010). Unmirroring pedagogies: Teaching with intersectional and transnational methods in the women and gender studies classroom. Feminist Formations, 22(1), 136-162.

Ellsworth, E. (1997). Teaching positions. New York: Teachers College Press.

Falk-Rafael, A., Chinn, P. Anderson, M., Laschinger, H. \& Rubotzky A. (2004). The effectiveness of feminist pedagogy in empowering a community of learners. Journal of Nursing Education, 43(3), 107-115.

Fraser, N. (2009). Scales of justice: Reimagining political space in a globalizing world. New York, NY: Columbia University Press.

Ganote, C. \& Longo, P. (2015). Education for social transformation: infusing feminist ethics and critical pedagogy into community-based research. Critical Sociology, 41(7/8), 1065-1085.

Grewal, I. (2006) Transnational America: Feminism, diaspora, neoliberalisms. Durham, NC: Duke University Press.

Guo, Y. \& Hébert, Y (2014). Educational integration of immigrant children and youth: policy ineffectiveness and its consequences for learners and society. In Kenise Murphy Kilbride (ed.), Immigrant Integration: Research implications for future policy (pp. 171-188). Toronto: Canadian Scholars Press.

Hébert, Y. (1990). Syllabus formation langagière gènèrale. Ottawa, ON: Canadian Association of Second Language Teachers.

Hemmings, C. (2011). Why stories matter: The political grammar of feminist theory. Durham, NC: Duke University Press.

Hobbs, M. \& Rice, C. (2011). Rethinking women's studies: Curriculum, pedagogy and the introductory course. Atlantis: Critical studies in gender, culture and social justice, 35(2), 139-149.

Hung-Chang, L. \& Wang, Y (2015). Creating a positive learning environment for students with English classroom anxiety. Psychological Reports, 116(2), 631-646.

Joseph, M. (2013). Risking justice: Women's studies beyond measure. Feminist Formations, 25(2), $135-$ 142.

Kannen, V. (2014). These are not 'regular places': Women and gender studies classrooms as heterotopias. Gender, Place \& Culture, 21(1), 52-67.

Karpinski, E. (2007). 'Copy, Cut, Paste': A reflection on some institutional constraints of teaching a big intro course. Resources for Feminist Research, 32(3), 44-53.

Engaged Scholar Journal: Community-Engaged Research, Teaching, and Learning 
Kashima, E., \& Loh, E. (2006). International students' acculturation: Effects of international, conational, and local ties and need for closure. International Journal of Intercultural Relations, 30(4), 471-85.

LaMantia, K., Wagner, H. \& Bohecker, L. (2015). Ally development through feminist pedagogy: A systemic focus on intersectionality. Journal of LGBT Issues in Counseling, 9(2), 136-153.

Landfill Harmonic. (2012). Youtube video. Posted by LandfillHarmonic, November 17, 2012. Retrieved from https://www.youtube.com/watch?v=fXynrsrTKbI

Maparyan, L. (2012). Feminism. In C.M. Orr, A. Braithwaite, D. Lichenstein (eds.). Rethinking women's and gender studies. New York: Routledge, 17-33.

Motta, S.C (2013). Teaching global and social Justice as transgressive spaces of possibility. Antipode, 45(1), 80-100.

Murphy, M.C. \& Zirkel, S. (2015). Race and belonging in school: How anticipated and experienced belonging affect choice, persistence and performance. Teachers College Record 117(12), 1-40.

Odora Hoppers, C. (2008). Lifelong learning in Africa: Lessons, experiences and opportunities from cultural and cognitive justice [oral presentation] UNESCO, 29 October 2008. http:// unesdoc.unesco.org/images/0016/001636/163618e.pdf

Phiri, A. (2014/5). Critical spaces: Processes of othering in British institutions of higher education. Journal of Feminist Scholarship, 7/8, 13-27.

Quek, K, Eppler C., \& Morgan M. (2014). Qualitative study on cis-male gender perspectives in the couple and family therapy classroom. Journal of Family Therapy, 26(4), 199-217.

Rosenberg, S. (2010). Facing losses/losing guarantees: A meditation on openings to traumatic ignorance as a constitutive demand. In R. Crownshaw, J. Kilby, A. Rowland (eds.), The future of memory (pp. 245-263). New York: Berghahn Books.

Russo, A (2006). The feminist majority foundation's campaign to stop gender apartheid. International Feminist Journal of Politics 8(4), 557-580.

Snyder, A (2005). Transnational dialogue: Building the social infrastructure for transnational feminist networks. International Journal of Peace Studies, 10(2), 69-88.

Statistics Canada (2012). 2011 Census of population: linguistic characteristics of Canadians, retrieved from www12.statcan.gc.ca/census-recensement/2011/as-sa/98-314-x/98-314-x2011001eng.pdf

Wanyenya, P. \& Lester-Smith, D. (2014/5). Neoliberalism and public university agendas: Tensions along the global/local divide. Journal of Feminist Scholarship, 7/8, 93-101.

Wiegman, R. (2012). Object lessons. Durham, NC: Duke University Press. 